\title{
Wakaf Uang : Solusi Meningkatkan Kesejahteraan Masyarakat di Masa Pandemi COVID-19
}

\author{
Rini Hayati Lubis ${ }^{1}$, Sri Indah Lestari², Hawanisa Harahap ${ }^{3}$ \\ 1,2,3Institut Agama Islam Negeri Padangsidimpuan \\ 1,2,3Jl. T. Rizal Nurdin Km. 4,5 Sihitang 22733, Kota Padangsidimpuan \\ Email: hayatirini65@gmail.com ${ }^{1}$
}

\begin{abstract}
Abstrak
Pandemi covid-19 mengakibatkan lemahnya perekonomian masyarakat, sehingga menyebabkan pertumbuhan ekonomi suatu Negara mengalami kemunduran, maka dari itu diperlukan adanya suatu alternatif untuk meningkat pertumbuhan ekonomi salah satunya adalah wakaf. Saat ini wakaf uang mencapai Rp 244 miliar dengan jumlah nazir wakaf uang melapor 111 lembaga sedangkan untuk lembaga wakaf uang mencapai 272, artinya sekitar 161 lembaga yang belum melaporkan dana wakaf uang terkumpul diakibatkan lemahnya tingkat pengetahuan terhadap pengelolaan wakaf uang tersebut. Disimpulkan bahwa masih lemahnya sistem pengelolaan manajemen wakaf uang sehingga belum terealisasinya wakaf uang tersebut ke masyarakat, tetapi apabila terkumpulnya dana wakaf uang akan menjadikan suatu instrument baru bagi pemerintah untuk meningkatan perekonomi khususnya selama pandemi ini. Terealisasinya dana wakaf dengan baik, pada akhirnya akan meningkatkan tingkat kepercayaan wakif terhadap pengelolaan wakaf yang transparan dan akuntabilitas, maka dari itu diharapkan perlunya sosialasi ke masyarakat terhadap perana wakaf uang tersebut, dan memberikan pelatihan bagi nazir untuk dapat mengelola wakaf tersebut berbasis teknologi.
\end{abstract}

\section{Kata Kunci: Kesejahteraan, Pandemi Covid-19, Wakaf uang}

\section{Abstract}

The Covid-19 pandemic has resulted in a weakening of the people's economy, which has caused the economic growth of a country to decline, therefore an alternative is needed to increase economic growth, one of which is waqf. Currently, cash waqf has reached $R p .244$ billion with the total nazhir of cash waqf reporting 111 institutions while for cash waqf institutions reaching 272, meaning that around 161 institutions have not reported collected cash waqffunds due to a weak level of knowledge about the management of cash waqf. It can be concluded that the money waqf management system is still weak so that the cash waqf has not been realized to the public, but if the cash waqf funds are collected it will make a new instrument for the government to improve the economy, especially during this pandemic. The realization of good waqf funds will ultimately increase the level of trust in waqf management which is transparent and accountable, therefore it is hoped that there is a need for socialization to the public regarding the role of the money waqf, and providing training for Nazhirs to be able to manage these waqf based on technology.

Keywords: Cash Waqf, Covid-19 Pandemic, Welfare 


\section{PENDAHULUAN}

Covid-19 telah menjadi perhatian publik di banyak negara termasuk Indonesia sejak kemunculannya di akhir tahun 2019. Pandemi ini tekah terbukti memberikan tekanan pada berbagai sisi kehidupan manusia seperti ekonomi, sosial dan lainnya. Kondisi perekonomian menjadi semakin terancam jika tidak diikuti dengan upaya agresif untuk mengatasinya. Secara umum kondisi ini telah menyebabkan tingkat pendapatan masyarakat menurun sedangkan pengeluara cenderung tetap. Pada awal pandemi, pendapatan masyarakat menurun antara 30-70 persen. Masyarakat harus mensiasati pola pengeluaran keluarga untuk menyesuaikan dengan tingkat pendapatan dan mencari sumber penghasilan tambahan untuk tetap mempertahankan pola pengeluaran tersebut(Kurniasih, 2020).

Indonesia saat ini tengah dihadapkan pada masalah kesejahteraan. Dampak yang diakibatkan pandemi ini yaitu guncangan ekonomi dan bertambahnya angka kemiskinan. Kondisi perekonomian yang belum stabil berdampak pada tingkat pendapatan dan kesejahteraan masyarakat. Hal ini membutuhkan upaya berbagai pihak untuk memulihkan guncangan tersebut. Indonesia dengan jumlah penduduk muslim terbesar di dunia dapat memberikan peran terbaiknya melalui berbagai cara untuk mengatasi pandemi ini. Badan Amil Zakat Nasional (BAZNAS), LAZNAS serta BWI bekerja sama dengan berbagai kementerian ikut turut serta membantu mengatasi dampak akibat pandemi ini. BAZNAS memiliki program utama dalam penerimaan dana ZISWAF, yaitu cash for work yang dimana akan menerima bantuan logistik keluarga. Bantuan paket logistic keluarga dapat diberikan dalam bentuk non-tunai maupun tunai. Sektor sosial keuangan Islam pada kondisi saat ini sangat diperlukan untuk mendukung berbagai program yang diharapkan dapat membantu masyarakat yang terdampak covid-19 demi kesejahteraann ummat (Amanda dkk., 2021).

Islam mengajarkan bahwa kesejahteraan masyarakat merupakan tanggung jawab bersama. Tanggung jawab ini lebih di titik beratkan pada kelompok yang memiliki kelebihan harta. Kelompok ini berkewajiban mendistribusikan sebagian dari hartanya untuk disalurkan kepada kelompok yang tidak memiliki kelebihan harta. Tujuan distribusi dalam Islam memiliki yaitu 1) menjamin pemenuhan kebutuhan dasar, 2) keseimbangan distribusi pendapatan dan kekayaan, 3) mengeliminasi kesenjangan ekstrim (Beik \& Arsyianti, 2019). Distribusi pendapatan dapat dilakukan dengan dua bentuk yaitu yang bersift wajib dan sunah. Distribusi pendapatan yang bersifat wajib yaitu zakat sedangkan yang bersifat sunnah yaitu sedekah infaq, wakaf dan hibah (Suryani, 2018). Sumber-sumber penerimaan dari sektor sosial keuangan Islam harus dimanfaatkan semaksimal mungkin untuk mempercepat pemulihan ekonomi yang melanda Indonesia. 
Wakaf merupakan ibadah sunah yang sifatnya amalan jariyah. Jenis harta benda yang dapat diwakafkan terdiri dari harta tidak bergerak dan benda bergerak. Harta benda yang tidak bergerak meliputi tanah, bangunan dll. Sedangkan harta bergerak yang dapat diwakafkan adalah harta benda yang tidak dapat habis sekali konsumsi seperti uang, logam mulia, surat berharga, kenderaan dan lainnya. Wakaf uang mulai dikenal sejak disahkannya UndangUndang No. 42 tahun 2004 tentang wakaf. Wakaf uang memiliki keunggulan yaitu memudahkan mobilisasi dana wakaf dan memberikan kepada calon wakif untuk berwakaf dalam nilai berapa pun tanpa harus menunggu harus menjadi orang yang raya raya (BWI, 2021)

Wakaf uang masih belum banyak dikenal oleh masyakat Indonesia. Jika dilihat dari tingkat literasi terkait dengan wakaf uang, masyarakat Indonesia dikategorikan pada tingkat literasi rendah(Ekawaty \& Muda, 2015). Keputusan calon wakif untuk berwakaf dipengaruhi banyak faktor diantarannya persepsi, religiusitas, pemahaman dan lainnya. Tingkat literasi dan pemahaman tentang wakaf uang yang minim akan berdampak pada lambatnya perkembangan wakaf uang yang berhasil dihimpun. Hal ini membuat potensi yang dimiliki Indonesia sebagai negara dengan jumlah penduduk terbesar di dunia menjadi tidak dapat dimanfaatkan secara maksimal.

Berbagai permasalahan-permasalahan yang dihadapi Indonesia dalam mengembangkan dan memanfaatkan potensi wakaf uang melatarbelakangi dilakukannya penelitian ini. Penelitian ini tertujuan untuk mengetahui peranan wakaf uang dalam meningkatkan kesejahteraan masyarakat di masa pandemi COVID-19.

\section{KAJIAN TEORITIS}

Berdasarkan bahasa wakaf terbagi atas dua bentuk yaitu masdar dari waqafa artinya menahan. Menurut Ibnu Faris wakaf ialah menetap dalam sesuatu, sedangkan berdasarkan golongan hanabila arti wakaf adalah menahan harta yang dapat dimanfaatkan, namun barangnya masih tetap, dengan cara memutuskan tasharuf wakif dan lainnya untuk dipergunakan dalam perkara yang mubah atau dengan kata lain untuk kebaikan demi takarrub kepada Allah. Konsep wakaf ini merupakan salah satu instrument keuangan publik yang sukarela di dalam perekonomian sehingga dapat ditemukan sudut pandang peranan wakaf untuk konstruksi ekonomi modern, dan dapat mengintegrasikan nilai-nilai tersebut guna mewujudkan kesejahteraan di masyarakat (Mulyono, 2020).

Konsep kesejahteraan adalah tujuan dari ajaran islam dalam bidang ekonomi yang mana kesejahteraan adalah bagian dari rahmatan lilmalamin, maksud kesejahteraan dalam konteks islam berdasarkan Al-Qur'an ialah mematuhi aturan yang telah ditetapkan oleh Allah JISFIM: Journal of Islamic Social Finance Management, Volume 2, No 1 Tahun 2021 http://jurnal.iain-padangsidimpuan.ac.id/index.php/JISFIM 
SWT hal ini berdasarkan dalam surat Al-Nahl :97, Thaha 117-119, Al-A'raf : 10, Al-Nisa;9, AlBaqarah : 126 (Purwana, 2014). Tercapainya kesejahteraan masyarakat apabila menunjukan adanya ukuran hasil pembangunan masyarakat dalam mencapai kehidupan masyarakat yang lebih baik, adapun yang dimaksud dari kehidupan yang baik yaitu memiliki beberapa indikator yaitu 1). Peningkatan kemampuan dan pemerataan distribusi kebutuhan dasar seperti sandang pangan, 2). Peningkatan tingkat kehidupan, tingkat pendidikan lebih baik, tingkat pendapatan, dan peningkatan atensi terhadap budaya dan nilai-nilai kemanusian, 3). Memperluas skala ekonomi dan ketersedian oilihan sosial individu dan bangsa. Dapat disimpulkan kesejahteraan masyarakat adalah terpenuhinya kebutuhan dasar yang tercermin dari ketiga indikator tersebut (A’yuni, 2018).

Selain dari ibadah wakaf juga memberikan sejuta manfaat untuk kemaslahatan bagi orang banyak dimana wakaf dapat berperan dalam pembangunan ekonomi secara langsung di berbagai sektor seperti pendidikan, kesehatan dan tempat ibadah, dengan adanya kualitas pendidikan yang baik bersumber dari wakaf akan memberikan dampak positif terhadap indesk manusia itu sendiri, sehingga kualitas manusia juga meningkat, begitu juga dengan kesehatan apabila kualitas kesehatan baik maka secara tidak langsung akan berdampak kesejahteraan masyarakat, hal yang serupa dengan tempat beribadah yang memperuntukan dalam menuntut ilmu sehingga dapat menyuburkan tingkat rohani, karena pembangunan ekonomi itu tidak hanya bersifat fizikal akan tetapi diperlukan adanya insani dalam kemajuan pembangunan ekonomi, maka dari itu dapat disimpulkan terlaksananya efektif dan efesien program wakaf tersebut akan terpenuhinya tingkat kesejahteraan manusia berdasarkan tiga indikator tersebut (Ab Rahman, 2009).

\section{METODE PENELITIAN}

Metode penelitian ini mengaplikasikan penelitian kualitatif yang bersifat deskriptif atau dengan istilah deskriptif kuantitatif artinya bertujuan untuk menemukan fakta dengan interprestasi yang tepat dan melibatkan beberapa kombinasi data bersumber dari observasi, wawancara dan dokumentasi sehingga menghasilkan suatu analisis dan menjadikan suatu kesimpulan dari suatu pertanyaan. Dalam penelitian ini mengunakan pendekatan kualitatif berbasis dokumen atau teks yaitu penelitian berfokus dan mengkaji pada analisis atau interpretasi bahan atau tertulis berdasarkan konteks yang mana sumber bahan tersebut dari catatan yang terpublikasi, buku teks, surat kabar, majalah, artikel dan lain-lainnya sehingga diperoleh kredibilitas yang tinggi (Ali, 2015; Suwarsono, 2016) 


\section{HASIL DAN PEMBAHASAN}

\section{Konsep Kesejahteraan Dalam Ekonomi Islam}

Tujuan dari pertumbuhan ekonomi yaitu meningkatkan kesejahteraan manusia. Terciptanya pertumbuhan ekonomi tidak terlepas dari peranan lapang pekerjaan yang akhirnya akan meningkatkan pendapatan rill penduduk, ini merupakan salah satu indikator tingkat kesejahteraan. Artinya meningkatnya pendapatan seseorang maka akan memengaruhi kebahagian orang tersebut dimana kebahagian merupakan salah satu indikator dari kesejahteraan (Sodiq, 2015). Akan tetapi tidak selamanya pendapatan menjadi tolak ukur kesejahteraan baik secara individu maupan Negara, karena bertambahnya pendapatan belum tentu meningkatkan standar hidup rill. Tidak berpengarunya pendapatan terhadap kesejahteraan disebabkan adanya pengaruh savings artinya bahwa masyarakat disini lebih memfokuskan alokasi pendapatannya sebagai tabungan sehingga berdampak pada penurunan daya beli dan akhirnya memengaruhi kualitas hidup. Begitu pula dengan Negara dimana pendapatan yang diperoleh dialokasikan untuk keperluan milter atau hal lain yang hasilnya hanya dinikmati oleh pemilik modal saja ataupun kelompok elit, sedangkan untuk masyarakat dengan ekonomi menengah ke bawah tidak dapat memperolah manfaat atas yang diperbuat oleh negara sehingga tingkat kemiskinan tetap tidak berkurang walaupun pendapatan Negara meningkat (Almizan, 2016).

Konsep kesejahteraan memiliki empat indicator utama yaitu 1) sistem nilai islam, pada hakikatnya kesejahteraan tidak dapat diraih apabila menentang ketetapan dari Allah karena aturanNYA merupakan sumber kesejahteraan sejati, 2) kekuatan ekonomi (industri dan perdagangan), supaya kegiatan ekonomi dapat berjalan dengan baik tidak terlepas peranan sektor rill, terwujudnya sektor rill terletak pada kekutaan industri dan perdagangan sehingga dapat menyerap angkatan kerja paling banyak pondasi inilah yang menjadikan terbentuknya ekonomi syariah, bahkan keuangan dalam islam didesain untuk memperkokoh sektor rill karena seluruh akad dan transaksi keuangan syariah berbasis pada sektor rill, 3) pemenuhan kebutuhan dasar dan sistem distribusi, terpenuhinya kebutuhan dasar individu maka akan terwujudnya kesejahteraan tersebut akan tetapi pada kenyataannya hanya sebagain kecil saja kelompok masyarakat yang dapat memenuhi kebutuhan dasarnya disinilah diperlukan adanya sistem distribusi ekonomi secara syariah memiliki peranan penting dalam menentukan kualitas kesejahteraan hingga dapat menurunkan angkat kemiskinan dan kesenjangan bahkan semua lapisan dapat menikmati perputaran roda perekonomian, 4) keamanan dan ketertiban sosial artinya kesejateraan dapat diperoleh melalui dengan rasa aman dan damai sehingga tidak akan terjadinya konflik antara beberapa kelompok di masyarakat bila kesejateraan tercipta. Dalam pandangan islam terwujudnya kesejateraan diperlunya aspek kedaulatan ekonomi sesuai dengan maqashidi dan didasarkan pada kelas bawah masyarakat kedua aspek JISFIM: Journal of Islamic Social Finance Management, Volume 2, No 1 Tahun 2021 http://jurnal.iain-padangsidimpuan.ac.id/index.php/JISFIM 
tata kelola perekonomian yaitu adanya transparansi, profesionalitas, dan akuntanbilitas yang amah dan masuliyyah (Beik \& Arsyianti, 2019).

Islam mendeskripsikan konsep kesejateraan secara holistic yaitu itu berkaitan dengan material dan spiritural di kemas secara fallah (kemenangan dunia dan akhirat) hal inilah yang membedakan dengan konsep kesejateraan secara konvensional. Terwujudnya fallah yaitu terpenuhinya kebutuhan yang seimbangan sehingga berdampak pada mashlahah (kebaikan bersama) ini dikatakan sebagai fungsi kesejateraan sosial islami bersumber dari pemikiran AlGhazali yang menyatakan bahwa kegiatan ekonomi merupakan kewajiban sosial yang harus dilakukan oleh masyarakat dan telah ditetapkan oleh Allah SWT, adapun menjadikan suatu kewajiban dikarenakan oleh : 1) untuk memenuhi kebutuhan hidup masing-masing, 2) menciptakan kesejateraan bagi dirinya dan keluarganya, 3) untuk membantu orang lain yang sedang membutuhkan. Dari ketiga unsur tersebut dapat disimpulkan tercapainya kesejahteraan yakni terpenuhinya kepuasan fisik bersumber dari kedamaian mental dan kebahagian, terbentuknya kebahagian dan kedamaian mental diperoleh dari realisasi yang seimbangan antara kebutuhan materi dan rohani bagi setiap individu sehingga terbentuklah kesejahteraan sosial tersebut (Pusparini, 2015; Sodiq, 2015).

Secara harfiah kesejahteraan sosial yaitu kondisi terpenuhinya kebutuhan material, spiritural dan sosial agar dapat hidup layak serta mampu mengembangkan diri sehingga terlaksananya fungsi sosial ini berdasarkan UU No.11 Tahun 2009 tentang kesejahteraan sosial, diharapkan dengan terlaksananya kesejateraan sosial mampu mengurangi masalah sosial di tengah masyarakat (Kholis, 2015). Menurut Al-Ghazali terwujudnya kesejahteraan sosial (al-mashlahah) diperlukan instrument agar terciptanya keseimbangan ekonomi di tengah masyarakat yaitu konsep pendistribusian, distribusi dalam prespektif islam memiliki dua sistem utama yakni pertama sistem distribusi berlangsung melalui proses ekonomi (mekanisme pasar), kedua distribusi berlandasakan sosial kemasyarakatan (mekanisme non pasar), adapun cakupan dari mekanisme non pasar atau sosial kemasyarakatan yakni zakat, infak, shadaqah, warisan dan wakaf (Almizan, 2016; Munthe, 2014).

\section{Perkembangan Wakaf Di Indonesia}

Secara trimologi wakaf menurut para ahli fikih terbagi atas dua kata yaitu habas dan wakaf merupakan kata benda berbentuk jamak artinya menahan (al-imsak), mencegah atau melarang (al-man'u) dan diam (at-tamakuts). Maksud dari ditahan ialah menahan dari kerusakan, penjualan, dan semua tindakan yang tidak sesuai dengan tujuan wakaf atau juga memanfaatkan hasil yang ditahan dan dilarang bagi siapapun selain dari orang-orang yang termasuk berhak atas wakaf tersebut. Sedangkan wakaf berdasarkan konsep ekonomi adalah menahan harta selamanya atau sementara dengan tujuan untuk dimanfaatkan secara langsung 
atau tidak langsung maupun berulang-ulang dijalan yang diridhai Allah SWT untuk kebaikan bersama (Furqon, 2016). Wakaf adalah suatu bentuk penyerahan harta secara terang (sorih) atau sendirian (kinayah), harta yang telah diserahkan kepada pihak tertentu ditahan dan hanya manfaatnya saja diaplikasi dengan tujuan-tujuan kebaikan bersama(Ab Rahman, 2009). Pada umumnya alokasi dana wakaf diperuntukan sarana dan prasarana dalam mendukung kegiatan isalm, maka dari itu jenis-jenis wakaf terdiri dari empat unsur antara lain pertama berdasarkan peruntukannya seperti membangun fasilitas umum, kedua jenis hartanya terdiri dari harta bergerak seperti logam mulai, uang, surat berharga, dan lain-lain. Sedangkan harta tak bergerak yaitu tanah dan bangunan (Suwaidi, 2011), ketiga berdasarkan waktu, kepenggunaan objek (Nasution, 2006).

Badan Wakaf Indonesia (BWI) melaporkan bahwa potensi aset wakaf Indonesia dapat mencapai 2000 triliun per tahunnya sedangkan wakaf tanah diperoleh sebesar $420 \mathrm{Ha}$ (Kemenkeu, 2019; Intan, 2021). Besarnya jumlah aset wakaf yang dihimpun oleh BWI tidak terlepas dari jumlah populasi muslim di Indonesia dan islam merupakan agama mayoritas di Negara tersebut, ditambah lagi adanya landasan kuat dari ajaran agama islam yang mewajibkan bagi orang mampu untuk menolong sesama saudaranya, hal ini menyebabkan besarnya potensi aset wakaf dihimpun. Berdasarkan data dapat disimpulkan bahwa besarnya potensi aset wakaf yang dicapai per tahunnya menjadikan suatu modal bagi percepatan pertumbuhan ekonomi di Indonesia apalagi di saat pandemic covid-19, selain itu juga peranan wakaf menawarakan solusi untuk mengurangi tingkat angka kemiskinan(Syamsuri dkk., 2020). Manfaat yang ditawarkan wakaf untuk mendorong pertumbuhan ekonomi yaitu salah satunya sebagai modal usaha sehingga mampu membuka lapangan perkerjaan di berbagai sektor seperti pendidikan, kesehatan, hingga pemberdayaan ekonomi masyarakat dan ini menjadikan suatu sumber modal bagi perekonomian untuk jangka panjangnya, selain itu juga dana wakaf dapat dijadikan sabagi sumber pendanaan invofatif untuk pembangunan berkelanjutan dan pada akhirnya akan menurunkan angka kemiskinan dan meningkat kesejahteraan masyarakat(K. C. Kompas Cyber, 2017).

Akan tetapi pada kenyataan besarnya dana wakaf diperoleh tiap tahunnya belum mampu terealisasi dengan optimal diketahui bahwa sekitar 400 miliar yang mampu dialokasi dan wakaf ke masyarakat sedangkan untuk wakaf tanah terealisasi sebesar 337 Ha yang belum bersertifikat dan 168 Ha yang sudah bersertifikat untuk data wakaf tanah berdasarkan kementerian agama yaitu sekitar 161,579 Ha dan hanya mampu dialaokasikan sebesar (M. Kompas Cyber, 2019), penyebabnya terjadi hal ini dikeranakan masih lemahnya literasi baik nazir maupun wakif tentang manajemen wakaf ataupun peranan wakaf seperti halnya pada wakaf tanah yang dikelola hanya dominan digunakan untuk bangunan masjid, sekolah dan kuburan dan wakaf tanah yang dikelola masih ada yang belum bersertifikat, artinya bahwa JISFIM: Journal of Islamic Social Finance Management, Volume 2, No 1 Tahun 2021 http://jurnal.iain-padangsidimpuan.ac.id/index.php/JISFIM 
manejemen wakaf masih lemah (MES, 2017), pada hal wakaf tanah mampu manfaat yang besar bagi kesejahteraan masyarakat apabila di kelola dengan maka dari itu perlunya pemerintah untuk meningkatkan pemberdayaan dana wakaf untuk kelangsungan pertumbuhan ekonomi jangka panjangnya.

\section{Potensi Wakaf Uang Dalam Meningkatkan Kesejahteraan Masyarakat}

Wakaf uang atau istilah lainnya Cash Waqf (wakaf tunai) adalah wakaf yang dilakukan oleh seseorang, kelompok, lembaga atau badan hukum dalam bentuk uang yang disebut sebut sebagai wakif dan diserahkan kepada nazir (penerima dana wakaf) berada di sekitar lingkungan wakif tersebut Sering dengan berjalannya waktu wakaf uang diperkenalkan kembali oleh piawai M. A. Mannan dalam bentuk lembaga yang disebut Sosial Investment Bank Limited (SIBL) di Bangladesh, dari lembaga tersebut menawarkan produk berbentuk sertifikat wakaf tunai kepada aghniya (orang kaya) dengan dana yang terhimpun dikelola dengan professional sehingga memperoleh keuntungan dan akan disalurkan kepada mustadháfin (orang fakir miskin)(Hasan, 2010).

Saat ini perkembangan wakaf uang di Indonesia secara akumulasinya mencapai Rp 244 miliar dengan jumlah nazir wakaf uang melapor 111 lembaga sedangkan untuk lembaga wakaf uang mencapai 272, artinya sekitar 161 lembaga yang belum melaporkan dana wakaf uang terkumpul ini menjadikan suatu kendala atau faktor penghambat secara internal bagi perkembangan wakaf tersebut, nantinya diharapkan terhimpunnya dana wakaf uang akan dikembangkan dengan beberapa model yaitu wakaf kesehatan, wakaf masjid, pendidikan, wakaf produktif (Huda, 2021). Dana wakaf uang dikelola dengan baik memberikan dampak positif bagi kesejahteraan(A'yuni, 2018). Tidak diragukan lagi bahwa wakaf uang memberikan dampak positif baik terhadap pertumbuhan ekonomi sehingga menjadikan alternatif untuk mengentas tingkat kemiskinan (Arif, 2012; Syamsuri dkk., 2020). Berdasarkan dari penelitian sebelumnya menguraikan bahwa pernan wakaf uang terhadap kesejahateraan sosial memiliki dampak positif. Dilihat dari pengalaman beberapa negara islam menunjukan sistem pengelolaan wakaf uang sangat bervariasi berbasis teknologi menjadikan fungsi wakaf terealisasi dengan optimal sesuai ketentuan syariat islam yaitu pemerataan pendapatan (Mulyono, 2020)

Pandemic covid-19 memberikan dampak positif dan negatif, salah satu dampak negatifnya adalah melemahnya perekonomian negara mengakibatkan banyak masyakat kehilangan mata pencaharian mereka, maka dari itu diperlukan adanya solusi atau alternafif untuk memulihkan perekonomian tersebut. Solusi yang diberikan adalah peranan wakaf sehingga dijadikan sebagai instrument keuangan islam dikarenakan wakaf memiliki fleksibilitas dibandingkan instrument lainya selain itu wakaf tersebut dapat diintegrasikan JISFIM: Journal of Islamic Social Finance Management, Volume 2, No 1 Tahun 2021 http://jurnal.iain-padangsidimpuan.ac.id/index.php/JISFIM 
dengan instrumen keuangan komersial islam lainya (Hastuti, 2021), berdasarkan data dan penelitian sebelumnya menunjukan bahwa potensi wakaf uang sebagai alat untuk mengatasi permasalah ekonomi apalagi di saat pandemi ini. di ketahui berdasarkan informasi diperoleh bahwa sekitar 244 miliar dana wakaf yang terealisasi sedangkan dana terhimpun sebesar 2000 triliun. Melihat dari kondisi dana terhimpun disimpulkan bahwa dana wakaf masih banyak belum teralisasi artinya memberikan peluang atau potensi yang besar untuk mempercepat gerakan sektor riil dari berbagai sektor yang telah ditatapkan oleh BWI tujuan akhirnya adalah meningkatkan kesejahteraan masyakatkan akibat dari pemerataan pendapatan yang dikelola oleh BWI, akan tetapi setiap usaha dilakukan pasti ada halangan atau hambatannya,dapat disimpulkan perlunya adanya perubahan atau invosai baru terhadap sistem wakaf yang dikelolah berlandaskan dari pengalaman Negara islam menganut wakaf sebagai instrumen pendorong ekonomi salah satunya adalah pendistrubusian pendapatan.

\section{Peranan Wakaf Uang Dalam Distribusi Pendapatan}

Penyaluran atau distribusi merupakan bagian dari klasifikasi pembayaran berupa sewa, bungamodal, upah, dan laba yang terkaitan dengan tanggung jawab seorang pekerja, modal (investor) dan pengusaha-pengusaha, sedangkan pendapatan adalah suatu aliran uang atau daya beli yang dihasilkan dari penggunaan sumber daya properti manusia, arti pendapatan dalam skala teori ekonomi yaitu hasil yang diperoleh seseorang berbentuk uang atau material lainnyadiperoleh dari penggunaan kekayaan atau jasa-jasa manusia (Lubis, 2020).

Menurut para ahli ekonomi menyimpulkan bahwa distribusi pendapatan adalah setiap kegiatan yang menyalurakan barang atau jasa, dari produsen ke konsumen yang membutuhkan produk tersebut. Dalam konteks islam ada beberapa instrument dalam pemerataan pendapataan atau keseimbangan pendapatan yakni zakat, wakaf, infak dan sedakah, adapun landasaan wakaf, zakat dan lainnya dijadikan Instrumen dalam kegitan ekonomi ialah sistem distribusi redistribusi kekayaan artinya bahwa kecukupan dalam standar hidup yang baik (nisab). Konsep distribusi pendapatan menekankan adanya hak Allah SWT dan Rasul-Nya terhadap pendapatan yang diperoleh setiap muslim maka dari itu setiap muslim dianjurkan untuk berwakaf, dan kegiatan ini merupakan bagian dari ijtimai (jaminan sosial) pada akhirnya akan minimalisasikan kesejangan pendapatan(Almizan, 2016).

Dari urai diatas dapat disimpulkan pernan wakaf uang dalam pendistrubusi patut untuk dioptimalkan baik dari segi manajemen dan pengetahuan nazir dan wakif, serta tingkat kesedaran wakif terhadap perintah Allah SWT, karena pada dasarnya wakaf uang sebagai bentuk kemanusian dan ajaran islam. 


\section{Hambatan dan Strategi Dalam Mengembangkan Wakaf Uang}

Besarnya pontensi wakaf uang untuk meningkatkan kesajahteraan masyarakat tidak terlapas dari beberapa hambatan dalam mengembangakan potensi wakaf uang, salah faktor utama menajadikan terhambatnya pengelolaan wakaf uang ini adalah masih lemahnya pemahan masyarakat tentang wakaf uang, berdasarkan penelitian sebelumnya menunjukan adanya pengaruh positif antara tingkat pengetauhan terhadap perkembangan wakaf uang (Ismawati \& Anwar, 2019; Tanjung dkk., 2020). Selain itu juga adapun hambatan dalam pengembangan wakaf

Upaya yang dilakukan untuk mengoptimalkan dalam pengelolaan wakaf yaitu pertama penggunaan dalam pengelolaan wakaf perlu ditingkatkan lagi yang mencakup aspek perwakafan seperti sosialisasi ke masyarakat, sistem pembayaran atau donasi wakaf berbasis digital hingga sistem pengelolaan wakaf yang transparan sehinga menambah tingkat kepercayaan bagi wakif terhadap dana yang diserahkan kepada pihak wakaf (Sukmana, 2020), kedua regulasi peraturan perundang-undangan wakaf, ketiga adanya sosialisasi peraturan per UU wakaf dan pradigma baru wakaf, keempat sertifikat, inventarsi dan advokasi harta benda wakaf, kelima peningkat kualitas nazir dan lembaga wakaf, keenam mefasilitasi jalinan kemitraan inventasi wakaf serta memfasilitasi terbentuknya BWI (Indriati, 2017). Strategi utama untuk meningkatkan pengelolaam wakaf uang di Indonesia yaitu memberikan edukasi dan sosialisasi yang efek kepada masyarakat mengenai wakaf uang serta strategi pemasaranyang berinovatif, transparansi dan akuntabilitas dari lembaga wakaf tersebut (Tanjung dkk., 2020).

\section{KESIMPULAN}

Berdasarkan fenonema dimasa pandemi banyak terjadainya kestabilatan terutama pada pertumbuhan ekonomi, artinya sektor riil saat covid mengalami hambatan yang berpengaruh terhadap pendapatan masyarakat artinya hilangnya matapencaharian mereka, apabila masalah ini di selesai dengan tepat akibatnya perekonomian Indonesia akan mengalami depresi maka dari itu diperlukan adanya suatu tindakan atau kebijakan untuk mengatasi masalah tersebut, salah satunya yaitu peranan wakaf uang, berdasarkan dari analisa diperoleh bahwa peran wakaf uang dapat dijadikan keputusan yang baik, hal ini berdasarkan data yang diperoleh dan beberapa penelitian sebelum yang membahas tentang wakaf, hanya saya peranan wakaf uang ini dikategorikan efek hal ini disebabkan lemahnya literasi masyarakat terhadap wakaf uang dan pengelolaan manajemen wakaf, hal inilah yang menyebabkan Indonesia tertinggal dengan Negara isalamnya yang menjadi wakaf sebagai sumber negaranya, maka dari itu diharapkan adanya peranan pemerintah terhadap 
pengelolaan wakaf berbasis teknologi, sosialisai kepada masyarakt terhadap peranan wakaf uang sehingga menimbulkan kesadaran bagi wakif untuk menunaikan wakafnya, pengelolaan manajemen yang baik diperlukan adanya pelatihan khusus bagi nazir.

\section{DAFTAR PUSTAKA}

Ab Rahman, A. (2009). Peranan wakaf dalam pembangunan ekonomi umat Islam dan aplikasinya di Malaysia. Jurnal Syariah, 17(1), 113-152.

Ali, I. H. (2015). Penelitian Komunikasi Pendekatan Kualitatif Berbasis Teks. Jurnal Studi $\begin{array}{lll}\text { Komunikasi dan } \quad \text { Media, } & \text { 19(1), }\end{array}$ http://dx.doi.org/10.31445/jskm.2015.190109

Almizan, A. (2016). Distribusi Pendapatan: Kesejahteraan Menurut Konsep Ekonomi Islam. Maqdis: Jurnal Kajian Ekonomi Islam, 1(1), 63-82.

Amanda, G. R., Malihah, F., Indriyastuti, S., Khumairah, N., Tulasmi, T., \& Mukti, T. (2021). Pendayagunaan Zakat Pada Masa Pandemi Covid-19. Jurnal Ilmiah Ekonomi Islam, 7(1), 216-222. https://doi.org/10.29040/jiei.v7i1.1789

Arif, M. N. R. A. (2012). Wakaf Uang dan Pengaruhnya terhadap Program Pengentasan Kemiskinan di Indonesia. JURNAL INDO-ISLAMIKA, 2(1), 17-29. https://doi.org/10.15408/idi.v2i1.1649

A'yuni, D. S. (2018). PERAN WAKAF TERHADAP KESEJAHTERAAN MASYARAKAT. Al'Adalah: Jurnal Syariah dan Hukum Islam, 3(2), 120-130.

Beik, I. S., \& Arsyianti, L. D. (2019). Ekonomi pembangunan syariah. PT RajaGrafindo Persada.

BWI. (2021). Wakaf Uang Dalam Perspektif Hukum Islam dan Undang-undang | Badan Wakaf Indonesia | BWI.go.id. https://www.bwi.go.id/6159/2021/o3/16/wakaf-uangdalam-perspektif-hukum-islam-dan-undang-undang/

Ekawaty, M., \& Muda, A. W. (2015). Wakaf Uang: Tingkat Pemahaman Masyarakat dan Faktor Penentunya (Studi Masyarakat Muslim Kota Surabaya, Indonesia). IQTISHODUNA, 11(2), 73-83. https://doi.org/10.1886o/iq.v11i2.3704

Furqon, A. (2016). WAKAF SEBAGAI SOLUSI PERMASALAHAN-PERMASALAHAN DUNIA PENDIDIKAN DI INDONESIA. JURNAL HUKUM ISLAM. http://ejournal.iainpekalongan.ac.id/index.php/jhi/article/view/573

Hasan, S. (2010). Wakaf uang dan implementasinya di Indonesia. de Jure: Jurnal Hukum dan Syari'ah, 2(2), 162-177.

Hastuti, M. (2021, Februari 9). Solusi Wakaf Uang pada Masa Pandemi. Advertorial. https://adv.kompas.id/baca/solusi-wakaf-uang-pada-masa-pandemi/ 
Huda, N. (2021). Wakaf Uang dan Sistem Pengelolaan. https://www.google.com/url?sa=t\&rct=j\&q=\&esrc=s\&source=web\&cd=\&ved=2ahUK Ewiy9pyPssDwAhVXVHoKHT7ZDVUQFnoECAQQAA\&url=https\%3A\%2F\%2Fwww. bwi.go.id\%2Fwp-content\%2Fuploads\%2F2021\%2Fo3\%2FMateri-Rakornas-BWI_3O03-2021.pdf\&usg=AOvVawogm45RDhIaSq038u1PplP2

Indriati, D. S. (2017). Urgensi Wakaf Produktif Dalam Pembangunan Ekonomi Masyarakat. Jurnal Ilmiah Al-Syir'ah, 15(2), Article 2. https://doi.org/10.30984/as.v15i2.476

Intan, G. (2021). Jokowi Sebut Potensi Wakaf di Indonesia Sangat Besar. VOA Indonesia. https://www.voaindonesia.com/a/jokowi-sebut-potensi-wakaf-di-indonesia-sangatbesar/5750571.html

Ismawati, Y., \& Anwar, M. K. (2019). PENGARUH PERSEPSI MASYARAKAT TENTANG WAKAF UANG TERHADAP MINAT BERWAKAF UANG DI KOTA SURABAYA. Jurnal Ekonomika dan Bisnis Islam, 2(3), Article 3. https://jurnalmahasiswa.unesa.ac.id/index.php/jei/article/view/29788

Kemenkeu. (2019). Potensi Aset Wakaf Rp2.ooo Triliun, RI Butuh Database Nasional. https://www.djkn.kemenkeu.go.id/berita_media/baca/12866/Potensi-Aset-WakafRp200o-Triliun-RI-Butuh-Database-Nasional.html

Kholis, N. (2015). Kesejahteraan Sosial Di Indonesia Perspektif Ekonomi Islam. AKADEMIKA: Jurnal Pemikiran Islam, 20(2), 243-260.

Kompas Cyber, K. C. (2017, Agustus 24). Wakaf Diusulkan Jadi Modal Usaha Startup. KOMPAS.com. https://ekonomi.kompas.com/read/2017/o8/24/184215726/wakafdiusulkan-jadi-modal-usaha-startup

Kompas Cyber, M. (2019, September 27). Potensi Besar, Wakaf Produktif Belum Tersosialisasi dengan Baik. KOMPAS.com. https://money.kompas.com/read/2019/o9/27/201410426/potensi-besar-wakafproduktif-belum-tersosialisasi-dengan-baik

Kurniasih, E. P. (2020). Dampak Pandemi Covid 19 Terhadap Penurunan Kesejahteraan Masyarakat Kota Pontianak. https://feb.untan.ac.id/wpcontent/uploads/2020/12/Erni-1.pdf

Lubis, A. T. (2020). DISTRIBUSI PENDAPATAN DALAM PERSPEKTIF ISLAM: JIBF MADINA : Journal Islamic Banking and Finance, 1(1), 53-67.

MES, M. E. S. (2017, Februari 21). Pengelolaan Wakaf Di Tanah Air Perlu Perbaikan Menyeluruh. Ekonomi Syariah. http://www.ekonomisyariah.org/6111/pengelolaanwakaf-produktif-perlu-perbaikan-menyeluruh/

Mulyono, S. H. (2020). PERAN WAKAF SEBAGAI INSTRUMEN KEUANGAN PUBLIK DALAM PEREKONOMIAN. Kasaba: Jurnal Ekonomi Islam, 13(2), 122-137. https://doi.org/10.32832/kasaba.v13i2.3665

JISFIM: Journal of Islamic Social Finance Management, Volume 2, No 1 Tahun 2021 http://jurnal.iain-padangsidimpuan.ac.id/index.php/JISFIM 
Munthe, M. (2014). Konsep Distribusi dalam Islam. Jurnal Syariah, 2(1), 70-88.

Nasution, M. E. (2006). ZAKAT DAN WAKAF SEBAGAI PILAR DALAM SISTEM PEREKONOMIAN NASIONAL | Nasution, Ph.D | IQTISHODUNA. http://ejournal.uin-malang.ac.id/index.php/ekonomi/article/view/205/pdf_114

Purwana, A. E. (2014). Kesejahteraan dalam Perspektif Ekonomi Islam. Justicia Islamica, 11(1), 21-42.

Pusparini, M. D. (2015). Konsep Kesejahteraan Dalam Ekonomi Islam (Perspektif Maqasid Asy-Syari'ah). Islamic Economics Journal, 1(1), 45-59.

Sodiq, A. (2015). Konsep kesejahteraan dalam islam. Equilibrium, 3(2), 380-405. https://doi.org/10.21043/equilibrium.v3i2.1268

Sukmana, R. (2020, Agustus 3). Wakaf sebagai Kelaziman Baru. JawaPos.com. https://www.jawapos.com/opini/o3/o8/2020/wakaf-sebagai-kelaziman-baru/

Suryani, E. (2018). DISTRIBUSI PENDAPATAN DAN PEMENUHAN KEBUTUHAN DALAM EKONOMI ISLAM. Al Hurriyah: Jurnal Hukum Islam, 11(2), 61-86.

Suwaidi, A. (2011). Wakaf dan Penerapannya di Negara Muslim. Culture, 167, 168.

Suwarsono, S. (2016). Pengantar Penelitian Kualitatif. Hari Studi Dosen Program Studi Pendidikan Matematika, JPMIPA-FKIP Universitas Sanata Dharma, Yogyakarta.

Syamsuri, Rohman, P. F., \& Stianto, A. (2020). Potensi Wakaf di Indonesia (Kontribusi Wakaf dalam Mengurangi Kemiskinan). MALIA: Jurnal Ekonomi Islam, 12(1), 79-94. https://doi.org/10.35891/ml.v12i1.1939

Tanjung, H., Suhandi, T., \& Tanzil, W. (2020, Juli). Analisis Strategi Pengelolaan Wakaf Uang di Indonesia (Pendekatan Metode Delphi). http://jurnal.umt.ac.id/index.php/jieb/article/view/2592 